\title{
Long-term Sickness Absence Among Professionals: Investigating Gender, Socioeconomic Position and Care Work'
}

\section{Aleksander $\AA$ A. Madsen ${ }^{2}$}

PhD Candidate, Centre for the Study of Professions, OsloMet - Oslo Metropolitan University, Norway

\begin{abstract}
This study investigates whether the risk of long-term sickness absence among professionals depends upon their socioeconomic position and whether they do caring work. It also explores whether the variation in risk can be attributed to sociodemographic and labor market factors. The event history analysis is based on longitudinal register data from the entire population of Norwegian professionals from 2003 to 2013 . The results showed that both low socioeconomic position and being a care worker was associated with long-term sickness absence. The group with the highest risk was professionals of lower socioeconomic position doing caring work. While the results were similar for men and women, the relative risk of sickness absence was higher for male professionals. Sociodemographic and labor market factors partly explained the observed association, and even more so for men. Several candidate explanations for the remaining association as well as potential implications for social policy are discussed.
\end{abstract}

\section{KEYWORDS}

Care work / health inequalities / interpersonal work / long-term sickness absence / professionals / socioeconomic position / welfare professions

\section{Introduction}

rofessionals are a vital part of the modern welfare state and are invaluable for the functioning of the educational, health and legal system. Concerns over shortages of teachers and health care professionals in several European countries (European Commission 2014), including Norway (Gunnes \& Knudsen 2015; Roksvaag \& Texmon 2012), highlight the importance of minimizing attrition. A high rate of long-term sickness absence (LTSA) may impede this effort. Norway has the highest rate of sickness absence among the OECD countries (OECD 2013: 36), and this is associated with undesirable outcomes such as dependence on disability pensions (Kivimäki et al. 2004) and mortality (Vahtera et al. 2004).

This study explores differences in the risk of LTSA between professionals and test a classification of professions along two dimensions. Joining two strands of research on health outcomes, the classification captures a vertical division of socioeconomic position

\footnotetext{
${ }^{1}$ You can find this text and its DOI at https://tidsskrift.dk/njwls/index.

${ }^{2}$ Correspondence: Aleksander Å. Madsen, Centre for the Study of Professions, OsloMet - Oslo Metropolitan University, P.O. Box 4, St. Olavs plass, 0130 Oslo, Norway. E-mail: aleksander.madsen@oslomet.no
} 
(SEP), and a horizontal division of whether the primary function of the professional is to care for the welfare of others. While the socioeconomic gradient in sickness absence is well documented (Allebeck \& Mastekaasa 2004), the classifications are often crude and one-dimensional. Studies of care providers argue that caring work is stressful (Hochschild 2003; Maslach 2003). However, there is a lack of comparative studies of care professionals and research linking care work to LTSA. The novel contribution of this study is the investigation of whether SEP and doing care work is associated with LTSA among professionals, and whether sociodemographic and labor market factors explain the differences in risk, using longitudinal population data. By supplementing the common emphasis on differences between levels with the inclusion of a caring dimension, and by focusing specifically on professionals, it expands the research on occupational differences in the risk of LTSA.

The article is organized as follows. First, the Nordic context is outlined with an emphasis on social insurance policies and the role of professionals. Second, a classification of professionals according to SEP and care work is presented. Next, previous research on predictors of LTSA is reviewed. On the basis of the review, three hypotheses are proposed in addition to important sociodemographic and labor-market explanatory factors. Then, the data, method and results are presented. Finally, the results of the analyses are discussed in light of previous studies and their implications for social policy.

\section{Professionals in a Nordic welfare state}

The Nordic welfare states are characterized by their generous and universal policies known to promote population health (Bambra 2011). While the Nordic welfare regimes share many similarities, there are also several international differences (Bambra 2013). Concerns over budgets and demographic changes during the past two decades led to a number of reforms aiming to reduce costs and beneficiaries, weakening Nordic welfare state exceptionalism (Hvinden 2004). As a consequence, there has been an increase in conditionality, and only Norway has remained unique in universalism and generosity (Kangas \& Kvist 2013). For example, the Norwegian sickness benefit provides full compensation for loss of income due to sickness for up to one year, whereas several reforms have lowered the wage replacement levels and tightened the conditions in Sweden (Hagelund \& Bryngelson 2014). Moreover, a means-tested benefit and weaker employment protection during sick leave (Brage 2007) separates the flexicurity in Denmark from the protectionism of Sweden and Norway (Bambra 2013).

Professionals are central to the process of transforming welfare states. They are the frontline staff facing the challenge of population aging. Especially in the Nordic countries where the tasks of the family have been assumed by the state (Esping-Andersen 1999). For example, the global nursing shortage implies an aging nursing workforce caring for increasing numbers of elderly people (Oulton 2006). Furthermore, the question of a transforming and sustainable welfare state is intertwined with gender. Since women constitute a large share of welfare state professionals, demographic shifts (e.g., global aging) will increase the demand for their labor. The increase in female labor market participation of the last decades also means that more women qualifies for income replacement benefits (Hvinden 2004). This emphasizes the need to upheld labor market participation, knowing that women have a high and increasing level of sickness absence 
(Dale-Olsen \& Markussen 2010). Hence, there is potentially a shortage of supply and a challenge of retaining a professional workforce key to future welfare state functioning, and thus a need for knowledge of determinants associated with risk of LTSA for these groups.

\section{Theoretical framework: a classification of professionals}

There has been a call for novel and more detailed analyses of the relationship between the division of labor and individual-level outcomes in the wake of the educational expansion and the increasingly growing and heterogeneous salaried middle class (Oesch 2006). The 'occupationalization' of the labor market (Grusky 2005) has put the study of occupations on the agenda, of which professions are the most well organized (Freidson 2001). There is much debate about what defines professions. However, most agree that they are exclusive occupations occupying a distinctive segment of the occupational structure owing to processes of jurisdiction (Abbott 1988), closure (Murphy 1988), shelter (Freidson 2001) or monopoly (Larson 1977). Their exclusive labor market position grants them autonomy over work. Through their mandatory and particular higher educational training, professionals acquire their profession's abstract and complex body of formal knowledge, which they apply to particular cases (Abbott 1988). Thus, professionals differ from the crafts in their abstract academic knowledge and from academic generalists in their exclusive practical application of this specialized knowledge.

The study of the relative risk of LTSA among professionals is interesting for several reasons. First, professionals constitute a large part of the labor force in general and the middle-class in particular, and are vital to welfare state services. Second, it is well established that individuals working in the lower strata of the occupational structure have a higher risk of LTSA than those at the top (Allebeck \& Mastekaasa 2004). This calls for a more detailed analysis of different segments of the occupational structure. Comparing the risk among professionals contribute to nuancing our knowledge of occupational differences. Finally, it is more reasonable to study occupational differences in risk of sickness absence among professionals than other middle-class workers. The close connection between their specialized knowledge and practical application implies more homogeneity across workplaces compared to other occupations consisting of academic generalists and firm specific trainees. Therefore, it can be reasonable to attribute differences in risk of LTSA between professionals to some intrinsic traits of professional practice in general rather than just workplace-specific characteristics.

In addition to study the relative risk among all groups of professionals, I classify them along two dimensions common in the sociology of professions. First, I separate professionals according to their SEP. A professional's SEP refers to the social and material resources available to them through their position in the social hierarchy and is related to numerous health determinants (Galobardes et al. 2006a). According to Freidson (2001), several professions are in a subordinate position in the division of labor since they have not established sufficient cognitive and cultural authority to dominate their jurisdiction. These are often called semi- or para-professions (e.g., nurses and teachers) and are in contrast to ideal-type professions (e.g., physicians and architects). The former has often (but not necessarily) a shorter university college education, lower entry requirements, a less specialized and a more interdisciplinary education, a weaker 
knowledge base, less autonomy and control over work, more routine tasks, and more females (Brante et al. 2015; Etzioni 1969). I separate between professionals with high and low SEP to explore whether professionals with a lower position have a higher risk of LTSA.

Second, professionals are classified according to whether caring for the welfare of others is the main professional concern. The dichotomy employed here is frequently applied under different names where caring (Abbott \& Wallace 1990), personal service (Halmos 1967), personal (Larson 1977), and relational (Moos, 2004) professionals are contrasted to professionals who do not work in close contact with clients with personal needs. Caring professionals have a 'primary commitment to care for their clients; personalized care is central to their practice as professionals. The needs of clients are said to take precedence in their work' (Abbott \& Wallace 1990: 1). The interpersonal relation between client and caring professional entails helping the client to overcome some personal challenge, which often requires emotional and personal involvement. Many have argued that caring work implies health harming physical and mental strain (e.g., emotional labor or burnout) that can in turn heighten the risk of LTSA.

\section{Previous research on predictors of LTSA and hypotheses}

LTSA is associated with numerous factors (see Allebeck \& Mastekaasa 2004 for a comprehensive review). In the classification of professionals, I put forward SEP and caring work as important for explaining interprofessional differences in risk of LTSA.

The SEP of professionals may reflect health behavior (i.e., lifestyle factors), psychosocial processes (e.g., control and autonomy), and physical exposures (e.g., heavy lifting) (Galobardes et al. 2006a). Among these factors, previous studies indicate that physical work conditions are the main explanatory factor for occupational disparities in sickness absence (Christensen et al. 2008; Löve et al. 2013). While physical factors seem more important than psychosocial ones for explaining the social gradient, the latter has also gained support (Melchior et al. 2005; Niedhammer et al. 2008). According to stress theories (e.g., Karasek 1979), mismatch between demands and control cause strain, and control over work seems especially important (Michie \& Williams 2003). Professionals with a lower SEP may experience heavier physical and psychosocial demands (e.g., lifting or work-based stress) and have fewer resources (e.g., autonomy or control) to cope with these demands than professionals with a higher SEP. As prior research suggests, I expect there to be a difference in risk of LTSA according to the professional's SEP. The first hypothesis is:

Hypothesis 1: Professionals with a lower SEP will have a higher risk of long-term sickness absence relative to professionals with a higher SEP.

The argument for a distinction between caring and noncaring professionals is that the handling of clients with personal needs implies a heightened risk of LTSA. Workers in health care and social services have a high risk (Lund et al. 2007), and a recent study found that awkward lifting, threats of violence, actual violence, and emotional demands explained a substantial part of the difference in the risk of LTSA for women in these services compared with women in the general working population (Aagestad et al. 2016). 
While comparative research on whether care providers have a higher risk of LTSA is scarce, the hazards of caring work have been highlighted by studies of burnout (Maslach 2003) and emotional labor (Hochschild 2003). Research on burnout has found that caring work results in stress and exhaustion (Barron \& West 2007; Wieclaw et al. 2006), and burnout is associated with sickness absence (Ahola et al. 2008; Borritz et al. 2010). Emotional labor is also associated with sickness absence, both in the general working population (Aagestad, Johannessen et al. 2014; Lund et al. 2006) and in human service work (Indregard et al. 2017; Rugulies et al., 2007). In addition to the psychosocial factors associated with burnout and emotional labor, threats of violence and actual violence (Aagestad, Tyssen, et al. 2014; Michélsen et al. 2014; Rugulies et al. 2007) as well as physical strain (Andersen et al. 2012) have been found to predict sickness absence among workers caring for clients. In summary, there is evidence that interpersonal caring work increases the risk of sickness absence, but comparative studies are scarce. An ambition of this study is to explore whether caring professionals experience a higher risk of LTSA than other professionals. The second hypothesis is:

Hypothesis 2: Caring professionals have a higher risk of long-term sickness absence than non-caring professionals.

The two previous hypotheses imply that both the SEP and client orientation of a professional affect the risk of LTSA. However, the strain of interpersonal work may be contingent upon the professional's SEP, and either enhances or moderates it. Low SEP professionals constitutes the lower middle class and have less autonomy and are under greater supervision (Brante 2013), which could entail greater exposure to physical and psychosocial risks (Galobardes et al. 2006a). According to Wharton (1993), workers with less autonomy are more exposed to the negative consequences of emotional labor, while those with sufficient autonomy profit from interpersonal work. Moreover, recent reforms of standardization are believed to be in conflict with caring work resulting in straining working conditions (Trydegård 2012). Loss of professional discretion and autonomy following these reforms might be more prevalent among caring professionals of low SEP (Kamp \& Dybbroe 2016). Finally, low SEP professionals are frontline staff with frequent contact with clients with severe problems, such as the threats and violence experienced in nursing (Spector et al. 2014), whereas professionals with a high SEP may be spared the most straining client relationships because of their position. The final hypothesis is of an interaction effect of SEP and caring:

Hypothesis 3: The effect of doing interpersonal caring work on risk of long-term sickness absence is contingent upon the SEP of the professional. Low SEP caring professionals have the highest risk of LTSA.

Additionally, I will explore whether the risk of LTSA among professionals can be attributed to sociodemographic and labor market factors. First, the risk of LTSA might vary by gender since the labor market in Norway is highly gender segregated and women have higher rates of LTSA than men (Dale-Olsen \& Markussen 2010). Some studies have shown that physical working conditions explain more of the social gradient in sickness absence for women than for men (Christensen et al. 2008; Löve et al. 2013), implying an interaction between gender and SEP. Moreover, caring work might be more 
straining for men, as the relationship between emotional demands and sickness absence has been found to be stronger for them (Aagestad, Johannessen, et al. 2014; Lund et al. 2005). Hence, the association between LTSA and SEP and caring work could be dependent on gender.

Second, factors outside work, such as those related to the family, can confound the association between professionals and LTSA. Previous research has found that both divorce/separation (Dahl et al. 2015) and pregnancy (Rieck \& Telle 2013) entail a higher risk, while having children primarily implies a lower risk of sickness absence (Mastekaasa 2012). If family-related characteristics are unequally distributed among professionals, the differences in risk of LTSA can reflect this. In addition, since nonwestern immigrants are both overrepresented in some professional groups and have a higher risk of LTSA (Dahl et al. 2010), the analyses must take immigration background into consideration.

Finally, the variation in risk of LTSA could reflect several labor market factors. For instance, income is an indicator of SEP, which measures material resources available to improve health (Galobardes et al. 2006a) and is interrelated with education and occupation as determinants of sickness absence (Piha et al. 2010). A relationship between the SEP of professionals and LTSA could be the result of differences in pay levels. Furthermore, working-time arrangements could also be of importance. Higher levels of absence are associated with the shift work of healthcare professionals (Merkus et al. 2012) and some use part-time work as a coping strategy (Ingstad \& Kvande 2011). Workplace gender composition is another relevant factor since elevated levels of LTSA are found in both extremely male-dominated and female-dominated workplaces (Bryngelson et al. 2011). Lastly, professionals are distributed differently among the public and private sector, which might be of importance because of the lower levels of absence in the private sector (Mastekaasa 2016).

\section{Data and methods}

\section{Data and study population}

This study uses administrative register data provided by Statistics Norway and consists of official registers on welfare benefits, employment, income, and education for the entire Norwegian population. The strengths of register data are long panels, no selfreport bias, and practically no missing information. The population under study consists of all individuals born between 1950 and 1987 who, after receiving professional diplomas, were employed as professionals during the period of January 2003 until December 2013. Self-employed individuals were excluded owing to a lack of data.

I used information on both education and occupation to identify professionals, reflecting formal training as mandatory before qualifying for professional practice. The Norwegian Standard Classification of Education (NUS2000) and the International Standard Classification of Occupation (ISCO-88) provide detailed information on education and occupation. Table 1 summarizes the 25 groups of professionals identified based on the existence of some form of closure or jurisdiction through legislation or credentials. The concept of professions is contested and the occupational structure is ever changing. Thus, the list in Table 1 is not meant to be exhaustive but contains most professions 
Table I Classification of professions

\begin{tabular}{lll}
\hline & Caring & Noncaring \\
\hline High socioeconomic position & Clergyman & Architect \\
& Dentist & Economist (MBA/MPhil) \\
& Physician & Civil engineer \\
& Psychologist (cand. psychol.) & Lawyer \\
& Veterinary surgeon & Pharmacist \\
& & State authorized public accountant \\
Low socioeconomic position & Dental hygienist/technician & Bioengineer \\
& General teacher & Journalist \\
& Physiotherapist/ergonomist & Librarian \\
& Preschool teacher & Optician \\
& Radiographer/audiometrist & Pharmacy technician \\
& Registered nurse & Registered public accountant \\
& Social worker & Undergraduate engineer \\
\hline
\end{tabular}

Note: Social workers consist of social workers, social educators, and child welfare officers. General teachers include both general teachers and subject teachers. Economists holding a Master of Business and Administration (MBA) or Master of Philosophy (MPhil) in economics qualify for a statutory regulated title as 'civil' or 'social' economist. The two titles are not directly transferable to countries outside of Scandinavia.

and semi-professions and is consistent with previous research (Mastekaasa 2008; Tufte 2013). Close to all groups of professionals can be identified with one ISCO-88 code. It is primarily economists and engineers who are identified using several ISCO- 88 codes since economists often work as business executives and there are several subcategories of engineering. Furthermore, only individuals who had a professional education as their highest and latest registered level of education were included. The yearly information on occupation means that professionals can move in and out of the dataset. They were considered to be under risk of LTSA only when working in an occupation identified as a profession and holding a matching professional education.

On the basis of these selection criteria, the population consisted of 2,274,229 person-rows.

\section{Dependent variable: LTSA}

The data provide information on all physician-certified LTSAs ( $>16$ days) in the period from January 1, 2003, until December 31, 2013. Sickness absence was operationalized as a combination of two factors. The first of these is a dummy variable indicating the onset of absence. The variable indicates whether an observation (individual professional employment spell) ended in failure (LTSA). Each individual can have multiple failures, which would indicate that sickness absence is a recurrent event. Second, there is a variable containing time elapsed in days employed after either being registered as a professional or most recent failure to either failure (absence) or right censoring (end of professional employment or data period). The analyses did not distinguish between different grades of LTSA. 


\section{Professions and a typology of professions}

All professional groups as shown in Table 1 were included in the analysis as dummy variables with civil engineers as the reference category. Furthermore, Table 1 shows the classification of professionals according to SEP and orientation toward interpersonal caring work. In the analyses, the dimensions were included as dummy variables with professionals of high SEP not doing caring work as baseline.

I separated professionals into high and low SEP in a two-stage process. First, I identified professions based on whether they hold a subordinate position in the professional division of labor (e.g., nurses) or lack authority to dominate their jurisdiction (e.g., journalists). Second, to verify this classification and to help determine borderline cases (e.g., economists), I used two well-known indicators of SEP. Several occupational-based measures of SEP exist (Galobardes et al. 2006b). Both subjective evaluations of occupational standing and measures of employment relations and resources are commonly used. Both aspects were covered by using the Standard International Occupational prestige Scale (SIOPS) and the Erikson-Goldthorpe-Portocarero (EGP) class scheme (Ganzeboom \& Treiman 1996). Only clergy were not in accordance with these indicators but were classified as having a high SEP since they belong to classic ideal type professions and require a long university education.

Second, caring professionals were identified according to whether the basic premise of the professional practice is to care for the welfare of others and whether they involve a high degree of interpersonal encounters. The remaining noncaring professionals belong to the spheres of technology, architecture, economy, pharmacy, and law. The classification is in accordance with the categories of health professionals, teaching professionals, and social and elderly care workers in Wieclaw et al. (2006) and life professionals in Tufte (2013).

The classification could be sensitive to the inclusion and exclusion of particular professions. Appendix Figure S1 and S2 shows robustness checks of excluding each of the 25 professions from the classification in the analyses. The results remained robust.

\section{Sociodemographic and labor market factors}

The analyses were conducted separately by gender. Other sociodemographic factors included marital status [unmarried, married/cohabitating, divorced/separated, and widow(er)], number of children under 18 (none, 1, 2, and $\geq 3$ ), pregnancy (yes/no), and immigration status (Norwegian, first generation western, second-generation western, first-generation nonwestern, and second-generation nonwestern). Labor market factors were the log transformed yearly income (inflation adjusted to 2011), part-time work ( $\leq 30$ hours a week), percent of females at the workplace, and sector (public/ private).

\section{Control variables}

Dummy variables for year of birth were included to control for unmeasured heterogeneity between age cohorts. I controlled for number of prior spells of sick leave before the 
observation period (2003) or first registration of working as a professional $(0, \leq 3, \geq 4)$ to take sickness absence history into consideration. I also controlled for the distance of workplace from regional centers (urban/rural).

\section{Statistics}

The data are structured as individual professional employment spells. Each spell can end in either LTSA (temporary or permanent) exit from professional employment or right censoring. Subjects not in professional employment or already listed as long-term sickness absentees at a particular point in time cannot be at risk of another spell of LTSA at that time. Survival analysis is appropriate to model the risk of LTSA because time to event is of interest and the data are right censored (Allison 2014).

An extension of Cox proportional hazards regression was used to model the effect of working as a professional while controlling for other covariates. Conditional gap time models are appropriate because LTSA is an ordered repeatable event, and are the preferred solution for variance-corrected models in multiple failure data (Box-Steffensmeier \& Zorn 2002). In a conditional gap time model, time to LTSA is reset after each event. The analyses were clustered on individuals and stratified on order of events to account for the repeated nature of the data. This means that individuals were not at risk of a later event until they had experienced all previous events, and baseline hazards were allowed to vary by number of events experienced.

The primary advantage of the semiparametric Cox model is that it makes no assumption about the distributional form of the baseline hazard rate. However, it assumes that the effect of each variable is the same at all points in time (proportional). Violation of the proportionality assumption (the effect of type of profession is dependent on time) can cause biased estimates. Nonproportionality was examined using the tests recommended by Box-Steffensmeier and Jones (2004), and the results remained robust across various model specifications.

\section{Results}

The descriptive statistics in Table 2 shows the proportion of person-rows with spells of long-term sickness absence and the proportion or mean values of family related and labor market factors by type of professional. It also shows the total number of personrows and individuals. The average number of sickness absence spells per person-row was $17 \%$; however, it varied by type of professional. Professionals with high SEP not doing caring work had an average of $7 \%$, while professionals with low SEP doing caring work had $21 \%$. Other noteworthy differences between the different types is that professionals with low SEP doing caring work had a much larger stock of women, the lowest mean income, more often worked part-time, worked more often in the public sector, and were by far the most numerous.

Table 2 reveals that the professionals belonging to the different types of professions varied by several characteristics. In Table 3, the relative risk [hazard ratio (HR)] of long-term sickness absence according to type of professional is estimated using Cox regression. The analyses are separated by gender. Model 1 shows the unadjusted HRs, 
Table 2 Descriptive statistics (mean values)

\begin{tabular}{|c|c|c|c|c|c|}
\hline & $\begin{array}{l}\text { High SEP } \\
\text { noncaring }\end{array}$ & $\begin{array}{l}\text { Low SEP } \\
\text { noncaring }\end{array}$ & $\begin{array}{l}\text { High SEP } \\
\text { caring }\end{array}$ & $\begin{array}{l}\text { Low SEP } \\
\text { caring }\end{array}$ & Total \\
\hline Long-term sickness absence & 0.07 & 0.10 & 0.11 & 0.21 & 0.17 \\
\hline Women & 0.35 & 0.46 & 0.57 & 0.89 & 0.75 \\
\hline \multicolumn{6}{|l|}{ Marital status } \\
\hline Unmarried & 0.37 & 0.46 & 0.33 & 0.38 & 0.38 \\
\hline Married/Cohabitation & 0.56 & 0.47 & 0.58 & 0.51 & 0.52 \\
\hline Divorced/separated & 0.06 & 0.07 & 0.08 & 0.11 & 0.10 \\
\hline Widow(er) & 0.00 & 0.00 & 0.00 & 0.01 & 0.01 \\
\hline Women pregnant & 0.14 & 0.12 & 0.15 & 0.11 & 0.12 \\
\hline \multicolumn{6}{|l|}{ Number of children under 18} \\
\hline 0 & 0.38 & 0.43 & 0.38 & 0.37 & 0.38 \\
\hline । & 0.21 & 0.21 & 0.22 & 0.23 & 0.22 \\
\hline 2 & 0.29 & 0.26 & 0.26 & 0.27 & 0.27 \\
\hline$\geq 3$ & 0.12 & 0.11 & 0.14 & 0.13 & 0.13 \\
\hline \multicolumn{6}{|l|}{ Immigration status } \\
\hline Norwegian & 0.97 & 0.95 & 0.85 & 0.95 & 0.95 \\
\hline First-generation western & 0.01 & 0.01 & 0.07 & 0.02 & 0.02 \\
\hline Second-generation western & 0.00 & 0.00 & 0.00 & 0.00 & 0.00 \\
\hline First-generation nonwestern & 0.02 & 0.04 & 0.08 & 0.03 & 0.03 \\
\hline Second-generation nonwestern & 0.00 & 0.01 & 0.01 & 0.00 & 0.00 \\
\hline Part-time work & 0.02 & 0.08 & 0.16 & 0.32 & 0.24 \\
\hline Income (NOK) & 787559 & 500701 & 618201 & 370847 & 458689 \\
\hline Women at workplace & 0.40 & 0.44 & 0.75 & 0.83 & 0.73 \\
\hline Public sector & 0.25 & 0.33 & 0.84 & 0.88 & 0.74 \\
\hline Year of birth (median) & 1970 & 1972 & 197| & |97| & |97| \\
\hline Urban workplace & 0.87 & 0.77 & 0.72 & 0.65 & 0.70 \\
\hline \multicolumn{6}{|l|}{ Number of prior sick leaves } \\
\hline None & 0.72 & 0.62 & 0.68 & 0.40 & 0.49 \\
\hline$\leq 3$ & 0.24 & 0.30 & 0.26 & 0.40 & 0.36 \\
\hline$\geq 4$ & 0.04 & 0.08 & 0.06 & 0.20 & 0.15 \\
\hline Individuals (n) & 44722 & 34172 & 26133 & 182211 & 287238 \\
\hline Observations (n) & 290048 & 226906 & 199883 & | 557392 & 2274229 \\
\hline
\end{tabular}

Note: Observations are person-rows; SEP = Socioeconomic position; Norway, 2003-20I3.

model 2 adjusts for family related factors, immigration status, birth cohort, prior sick leaves, and distance from regional centers, and model 3 further adjusts for labor market factors.

The conditional gap time models show that low SEP and doing caring work was associated with a higher relative risk of LTSA. However, the magnitude varied by gender and was reduced after the introduction of relevant determinants. For men, compared to professionals with high SEP not doing caring work, which is the reference category, the unadjusted relative risk of LTSA at any point in time was $48 \%$ higher for professionals 
Table 3 Relative risk (hazard ratio) of long-term sickness absence according to type of professional (95\% Cl in brackets)

\begin{tabular}{|c|c|c|c|c|c|c|}
\hline & \multicolumn{3}{|l|}{ Men } & \multicolumn{3}{|l|}{ Women } \\
\hline & Model I & Model 2 & Model 3 & Model I & Model 2 & Model 3 \\
\hline \multicolumn{7}{|c|}{ Type of professional (baseline = high SEP noncaring) } \\
\hline Low SEP noncaring & $\begin{array}{l}\text { I.48**** } \\
{[1.41,1.55]}\end{array}$ & $\begin{array}{l}\text { I.39**** } \\
{[1.33,1.46]}\end{array}$ & $\begin{array}{l}1.37 * * * * \\
{[1.30,1.43]}\end{array}$ & $\begin{array}{l}\text { I.35*** } \\
{[1.31,1.40]}\end{array}$ & $\begin{array}{l}1.32 * * * * \\
{[1.28,1.37]}\end{array}$ & $\begin{array}{l}\text { I.30***** } \\
{[1.25,1.34]}\end{array}$ \\
\hline High SEP caring & $\begin{array}{l}1.65 * * * * \\
{[1.57,1.74]}\end{array}$ & $\begin{array}{l}\text { I.52**** } \\
{[1.44,1.60]}\end{array}$ & $\begin{array}{l}1.26 * * * * \\
{[1.19,1.34]}\end{array}$ & $\begin{array}{l}1.31 * * * * \\
{[1.27,1.36]}\end{array}$ & $\begin{array}{l}1.26 * * * 1 \\
{[1.22,1.30]}\end{array}$ & $\begin{array}{l}1.10 \text { ***** } \\
{[1.06,1.14]}\end{array}$ \\
\hline Low SEP caring & $\begin{array}{l}3.79 * * * * \\
{[3.65,3.94]}\end{array}$ & $\begin{array}{l}2.75 * * * \\
{[2.65,2.86]}\end{array}$ & $\begin{array}{l}2.08 * * * * \\
{[1.97,2.20]}\end{array}$ & $\begin{array}{l}1.96 * * * * \\
{[1.91,2.01]}\end{array}$ & $\begin{array}{l}1.79 * * * * \\
{[1.74,1.83]}\end{array}$ & $\begin{array}{l}1.61 \text { ***** } \\
{[1.57,1.66]}\end{array}$ \\
\hline \multicolumn{7}{|l|}{ Marital status (baseline = unmarried) } \\
\hline Married/Cohabitation & & $\begin{array}{l}0.90 * * * * \\
{[0.87,0.93]}\end{array}$ & $\begin{array}{l}0.90 * * * * \\
{[0.87,0.93]}\end{array}$ & & $\begin{array}{l}0.94 * * * * \\
{[0.93,0.95]}\end{array}$ & $\begin{array}{l}0.94 * * * * \\
{[0.93,0.95]}\end{array}$ \\
\hline Divorced/Separated & & $\begin{array}{l}1.07 * \\
{[1.01,1.12]}\end{array}$ & $\begin{array}{l}1.07 \text { *** } \\
{[1.02,1.13]}\end{array}$ & & $\begin{array}{l}1.21 * * * * * \\
{[1.19,1.24]}\end{array}$ & $\begin{array}{l}1.20 * * * * \\
{[1.18,1.23]}\end{array}$ \\
\hline Widow(er) & & $\begin{array}{l}0.85 \\
{[0.68,1.07]}\end{array}$ & $\begin{array}{l}0.84 \\
{[0.67,1.05]}\end{array}$ & & $\begin{array}{l}1.04 \\
{[0.98,1.10]}\end{array}$ & $\begin{array}{l}1.04 \\
{[0.99,1.11]}\end{array}$ \\
\hline Pregnant & & & & & $\begin{array}{l}7.82 * * * * \\
{[7.73,7.91]}\end{array}$ & $\begin{array}{l}7.82 * * * * \\
{[7.73,7.90]}\end{array}$ \\
\hline \multicolumn{7}{|c|}{ Number of children under 18 (baseline = none) } \\
\hline I & & $\begin{array}{l}1.01 \\
{[0.97,1.04]}\end{array}$ & $\begin{array}{l}1.01 \\
{[0.97,1.05]}\end{array}$ & & $\begin{array}{l}1.01 * \\
{[1.00,1.03]}\end{array}$ & $\begin{array}{l}1.02 * * * * \\
{[1.01,1.04]}\end{array}$ \\
\hline 2 & & $\begin{array}{l}0.99 \\
{[0.95,1.03]}\end{array}$ & $\begin{array}{l}0.99 \\
{[0.95,1.03]}\end{array}$ & & $\begin{array}{l}0.89 * * * * \\
{[0.88,0.90]}\end{array}$ & $\begin{array}{l}0.91 \text { ****** } \\
{[0.90,0.92]}\end{array}$ \\
\hline$\geq 3$ & & $\begin{array}{l}0.94 * \\
{[0.89,0.99]}\end{array}$ & $\begin{array}{l}0.95^{*} \\
{[0.90,0.99]}\end{array}$ & & $\begin{array}{l}0.78 * * * * \\
{[0.77,0.79]}\end{array}$ & $\begin{array}{l}0.81 * * * * \\
{[0.79,0.82]}\end{array}$ \\
\hline \multicolumn{7}{|c|}{ Immigration status (baseline = Norwegian) } \\
\hline First-generation western & & $\begin{array}{l}1.16 * * * * \\
{[1.06,1.27]}\end{array}$ & $\begin{array}{l}1.16 * * * * \\
{[1.06,1.26]}\end{array}$ & & $\begin{array}{l}1.07 * * * * \\
{[1.03,1.1 \mathrm{I}]}\end{array}$ & $\begin{array}{l}1.07 * * * * \\
{[1.04,1.11]}\end{array}$ \\
\hline Second-generation western & & $\begin{array}{l}0.85 \\
{[0.45,1.57]}\end{array}$ & $\begin{array}{l}0.85 \\
{[0.46,1.58]}\end{array}$ & & $\begin{array}{l}0.93 \\
{[0.79,1.09]}\end{array}$ & $\begin{array}{l}0.92 \\
{[0.78,1.09]}\end{array}$ \\
\hline First-generation nonwestern & & $\begin{array}{l}1.36 * * * * \\
{[1.27,1.45]}\end{array}$ & $\begin{array}{l}1.34 * * * * * \\
{[1.25,1.44]}\end{array}$ & & $\begin{array}{l}1.31 * * * * * \\
{[1.28,1.35]}\end{array}$ & $\begin{array}{l}1.29 * * * * \\
{[1.25,1.32]}\end{array}$ \\
\hline Second-generation nonwestern & & $\begin{array}{l}1.33^{*} \\
{[1.01,1.75]}\end{array}$ & $\begin{array}{l}1.31 * \\
{[1.00,1.73]}\end{array}$ & & $\begin{array}{l}1.35 * * * \\
{[1.23,1.48]}\end{array}$ & $\begin{array}{l}1.33 * * * * \\
{[1.22,1.46]}\end{array}$ \\
\hline Part-time & & & $\begin{array}{l}0.69 * * * \\
{[0.66,0.73]}\end{array}$ & & & $\begin{array}{l}0.88 \text { ***** } \\
{[0.87,0.89]}\end{array}$ \\
\hline Ln(income) & & & $\begin{array}{l}0.85 * * * * \\
{[0.82,0.87]}\end{array}$ & & & $\begin{array}{l}1.09 * * * * \\
{[1.07,1.10]}\end{array}$ \\
\hline Percent of females at workplace & & & $\begin{array}{l}1.04 * * * \\
{[1.03,1.04]}\end{array}$ & & & $\begin{array}{l}1.03 * * * * \\
{[1.03,1.04]}\end{array}$ \\
\hline Public sector & & & $\begin{array}{l}1.15^{* * * * *} \\
{[1.10,1.19]}\end{array}$ & & & $\begin{array}{l}1.15 * * * * \\
{[1.14,1.17]}\end{array}$ \\
\hline
\end{tabular}


(Continued)

\begin{tabular}{lllllll}
\hline & \multicolumn{7}{c}{ Men } & \multicolumn{5}{l}{ Women } \\
\hline & Model I & Model 2 & Model 3 & Model I & Model 2 & Model 3 \\
\hline Year of birth fixed-effects & No & Yes & Yes & No & Yes & Yes \\
Controls & No & Yes & Yes & No & Yes & Yes \\
Individuals (n) & 87176 & 87176 & 87176 & 200062 & 200062 & 200062 \\
Observations (n) & 562028 & 562028 & 562028 & 1712201 & 1712201 & 1712201 \\
\hline
\end{tabular}

Note: Significance probabilities: $* \mathrm{p}<0.05$, ** $\mathrm{p}<0.0 \mathrm{I}$, **** $\mathrm{p}<0.00 \mathrm{I} ; \mathrm{Cl}=$ confidence interval, SEP = Socioeconomic position, ref. = reference category; Stratified by order of events; $\uparrow=$ control for number of prior sick leaves and distance of workplace from regional centers; Cox proportional hazard regression model; Norway, 2003-2013, N = 2,274,229.

with low SEP not doing caring work (HR 1.48), 65\% higher for professionals with high SEP doing caring work (HR 1.65), and $279 \%$ higher for professionals with low SEP doing caring work (HR 3.79). Differences in the unadjusted relative risk of LTSA were comparatively lower for women: low SEP noncaring professionals had 35\% (HR 1.35), high SEP caring professionals had 31\% (HR 1.31), and low SEP caring professionals had $96 \%$ (HR 1.96) higher risk of LTSA compared to high SEP noncaring professionals. Hence, the unadjusted results support all three hypotheses and shows that (H1) SEP, $(H 2)$ caring work, and especially $(H 3)$ a combination of both implies a higher risk of LTSA for men than for women.

The introduction of family-related factors and the control variables in model 2 results in lower relative risk of LTSA according to type of professional, particularly for male low SEP caring professionals. Thus, the higher risk of LTSA for these professionals can partly be attributed to differences in age, prior sick leaves, marital status, pregnancy, number of children, and immigration status. In line with previous research, divorce/separation heightens the risk of LTSA while having more than one child lowers the risk. These associations were stronger for female than for male professionals. Nonwestern immigrants have a higher risk of LTSA, both for men and women, also in line with previous research.

The added labor markets factors in model 3 reduce the differences in risk of LTSA further for both types of caring professionals but, as in model 2, not significantly for low SEP noncaring professionals. For caring professionals, the higher risk of LTSA compared to high SEP noncaring professionals can partly be attributed to differences in worktime, income, workplace gender composition, sector, and distance of workplace from regional centers. In the fully adjusted model, men have a higher relative risk of LTSA than women. Male low SEP noncaring professionals have 37\% (HR 1.37), high SEP caring professionals have $26 \%$ (HR 1.26), and low SEP caring professionals have $96 \%$ (HR 1.96) higher risk of LTSA compared to male high SEP noncaring professionals, while the corresponding results for women are 30\% (HR 1.30), 10\% (HR 1.10), and $61 \%$ (HR 1.61), respectively. Part-time work reduces the risk of LTSA for both genders, supporting the notion of part-time work as a protection against absence. Increasing income decreases the risk of LTSA for men, while it, surprisingly, increases the risk for women. Public sector professionals of both genders have a higher rate of LTSA, and the rate increases with an increasing share of females at the workplace for men and women.

The classification of professionals could hide important interoccupational 


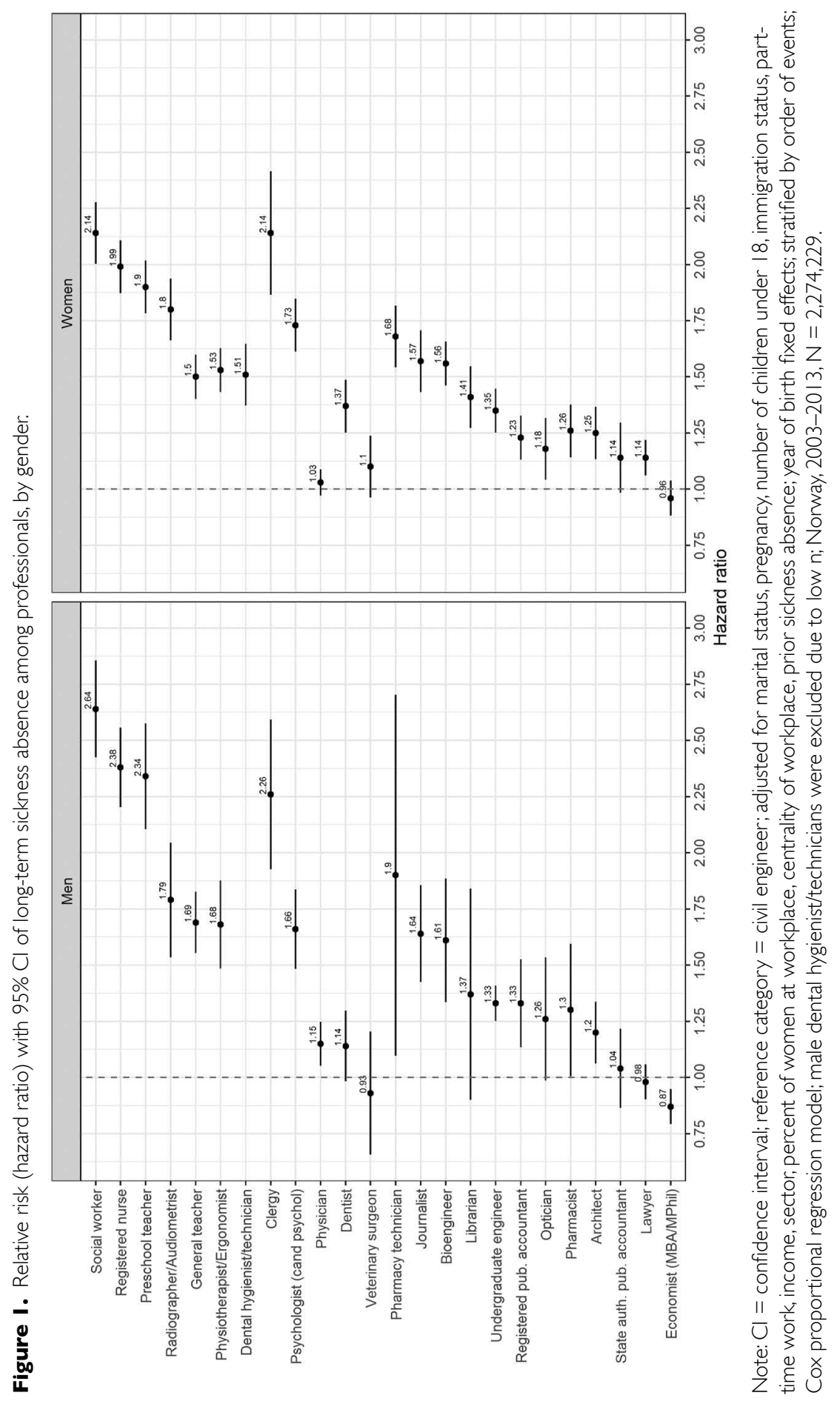


differences in risk of LTSA. Figure 1 shows the relative risk of professionals compared to civil engineers (baseline) adjusted for the same factors as in model 3 in Table 3 (see appendix figure $\mathrm{S} 3$ for unadjusted HRs). The figure shows that the two dimensions of the classification capture the variation in risk between professionals well for both genders, despite some overlap, and seems to follow a gradient. The most diverging results were among high SEP caring professionals. Furthermore, the magnitude of the relative risk compared to civil engineers seems substantial.

Professionals of low SEP doing caring work had all a higher risk of LTSA than civil engineers and other professionals of high SEP not doing caring work, for both genders. This was especially evident for healthcare professionals. The least consistent results were found for high SEP caring professionals. Clergy and psychologists, both male and female, had a high prevalence of LTSA comparable to low SEP caring professionals. These professionals have in common that they work with straining human troubles, which could possibly explain the high relative risk of LTSA. Physicians, dentists, and veterinary surgeons, on the other hand, had a comparatively lower risk of LTSA. Physicians are known for their high prevalence of sickness presenteeism (Aronsson et al. 2000), which could perhaps explain their low relative risk of LTSA. Among professionals not doing caring work, there was a distinct gradient from pharmacy technicians to economists. However, there were some overlap with caring professionals. Especially pharmacy technicians, journalists, and bioengineers had HRs of the same magnitude as teachers, physiotherapists/ergonomists, and radiographers/audiometrists. This similarity in risk of LTSA is perhaps due to these professions being borderline cases, as their work has a strong relational component comparable to caring professionals. For instance, pharmacy technicians and bioengineers deal with patients and clients in healthcare.

\section{Discussion}

The aims of this study were to investigate whether the risk of LTSA among professionals was dependent on their SEP and whether they were primarily oriented toward caring for the needs of others, and whether variation in risk could be due to sociodemographic and labor market factors. The analyses confirmed all three hypotheses: $(H 1)$ professionals of lower SEP had a higher risk of LTSA compared to professionals of higher SEP, (H2) professionals doing caring work had a higher risk compared to professionals not doing caring work, and (H3) a combination of low SEP and caring work entailed the highest relative risk of LTSA. While the two dimensions of the typology capture the differences in risk well, there were variations within the four types.

Overall, the results were similar for men and women. However, male caring professionals had a higher relative risk of LTSA, which was particularly evident for those of low SEP. This is in line with previous studies that have found that men are more vulnerable to the psychosocial risks of caring work, such as emotional demands (Aagestad, Johannessen, et al. 2014; Lund et al. 2005; Wieclaw et al. 2006). The higher risk for men in these female-dominated professions could also be the result of differential assignment of work tasks (Messing et al. 2003) or a specific job culture in female-dominated professions (Evans \& Steptoe 2002).

The differences in relative risk of LTSA between professionals due to SEP and caring work could partly be attributed to sociodemographic and labor market factors. 
They accounted for more of the relationship for men than for women since there was a more pronounced reduction in the HRs for men with the introduction of these factors, particularly for male low SEP caring professionals. Regarding the independent association between these factors and LTSA, family-related factors seemed more important for female professionals, and as found in other studies (Dahl et al. 2015; Mastekaasa 2012; Rieck \& Telle 2013), married/cohabitating women had a lower and divorced/separated had a higher risk, pregnancy multiplied the risk, and having more than one child under 18 were associated with a lower risk of LTSA. Moreover, first- and second-generation nonwestern immigrants of both genders had higher levels of LTSA, in line with previous research (Dahl et al. 2010). Labor market factors seemed equally important for men and women: Part-time work was associated with a lower risk of LTSA, which is perhaps due to less exposure to the straining effects of work. A study has found that part-time was used to reduce the strains of work among nurses (Ingstad \& Kvande 2011). Income is inversely related to LTSA (Piha et al. 2010), as found for men in this study. However, surprisingly, this was not the case for women. The fact that higher income was associated with a higher risk of LTSA for female professionals warrants further research. Finally, both the proportion of female coworkers and working in the public sector were positively associated with LTSA, as previously found (Bryngelson et al. 2011; Mastekaasa 2016).

Significant interprofessional differences in risk of LTSA for both men and women remained even after taking several important sociodemographic and labor market factors into account. While the results indicate correlations and any causal inferences must be made with caution, there are several plausible mechanisms that may explain the observed variation in LTSA between professionals. Firstly, low SEP and caring work may be associated with health hazards at work. While physical work conditions are the most likely explanations for the socioeconomic gradient in LTSA (Christensen et al. 2008; Löve et al. 2013), also psychosocial factors are pertinent (Melchior et al. 2005; Niedhammer et al. 2008). Similarly, certain physical and psychosocial hazards have also been linked to heightened risk of LTSA for caring work (Aagestad et al. 2016) and researchers have particularly emphasized the emotional demands as straining (Indregard et al. 2017; Rugulies et al. 2007).

Second, Tufte (2013) suggests that the value orientation or professional ethics of caring professionals may make them more prone to absence. The altruistic mindset, instilled through their education, urges care providers to involve themselves in helping others. Too much involvement can lead to emotional exhaustion and burnout, especially when facing clients with severe problems (e.g., cancer). A recent study found that nurses with high levels of altruistic prosocial motivation were more likely to report burnout than nurses with lower levels (Dill et al. 2016). Furthermore, prioritizing the needs of clients may lead to disregard of one's own health resulting in accumulated strain and sickness presenteeism, which is known to be high among caring professionals (Aronsson et al. 2000). Sickness presenteeism is associated with sickness absence (Gustafsson \& Marklund 2011).

Third, differences in risk of LTSA could be due to selection into occupations. A recent study found that the heightened risk of LTSA in female-dominated occupations (e.g., nursing) could be attributed to unobserved heterogeneity rather than occupationspecific characteristics (e.g., working conditions) (Melsom \& Mastekaasa 2017). Thus, it is likely that both men and women more inclined to be on sick leave are sorted into 
caring professions indicating that sorting mechanisms as opposed to work environment mechanisms are present. Likewise, there is evidence of selection being the most plausible explanation for the association between SEP and health (Foverskov \& Holm 2015). While this study considered several important determinants of LTSA, a limitation is the lack of control for unobserved heterogeneity.

Finally, the observed pattern may not be a result of differences in occupational hazards per se, but rather depends on whether the professional practice allows for minor sicknesses. It may be that professionals performing physically stressful tasks or caring for the sick have fewer opportunities to work when sick, whereas the flexibility often associated with high SEP jobs allows them to manage. The results of this study may reflect these conditions.

In addition to the suggested mechanisms, others are possible. This underscores the main limitation of this study - a lack of a causal design and explanatory variables accounting for the aggregated patterns of risk outlined by the typology. More research is needed to investigate the underlying mechanisms producing variation in risk between professionals. The strengths of this study, on the other hand, are the novel focus on types of professionals, and the typology employed provides a synthetization of two strains of research on work and health. The high-quality longitudinal population data following professional labor market careers for up to 11 years, and the treatment of LTSA as a recurrent event, thus avoid the underestimation of the risk that characterizes many studies (Christensen et al. 2007), gives a robust description of the relative prevalence of LTSA.

The present findings have implications for social policy. Policies aiming to combat the shortage of care workers can be summarized as those whose aim is to improve the conditions and attractiveness of caring work and those whose aim is to recruit new pools of workers (Hussein \& Manthorpe 2005). A high rate of absence among caring professionals can have consequences for the retention and recruitment of workers, and a high-risk low-staffed work environment can jeopardize the quality of care (Halbesleben et al. 2008). To begin with, besides temporarily weakening the workforce, sickness absence may have long-term effects on retention by weakening future labor market attachment (Bryngelson 2009; Gustafsson \& Marklund 2011). Moreover, a straining physical and psychosocial work environment, as indicated by high rates of LTSA, in addition to low wages (England et al. 2002), can be detriment to the attractiveness of caring work for both current and potential workers. For men, improving the conditions and appeal of caring work seems particularly important. They represent a new pool of workers to recruit from. However, both recruitment and retention of male workers can be impeded by the conditions of care work (Warming 2013), as highlighted by the higher relative risk of LTSA among male caring professionals in the present study.

The policy implications of a high rate of LTSA among caring professionals depend on institutional specificities. Compared to other developed countries, the Nordic welfare states manage the emerging care deficit primarily by public services (Anttonen \& Zechner 2011). A large public sector and generous universal policies can be advantageous for the retention and recruitment of caring professionals, as it provides better conditions for care workers in terms of relative wage levels (Hussein \& Manthorpe 2005) and reduces the individual consequences of becoming sick listed from working in a hazardous environment. However, a very high reliance on public spending can make these welfare states vulnerable to high levels of LTSA among care workers. It entails a large strain on budgets, especially as the care deficit urges expansion of the workforce and stresses 
the need to reduce absence rates. Reforms have been introduced to reduce costs, especially in Sweden and Denmark; however, the reduction in redistributive policies has not been replaced sufficiently by regulatory policies. Implementation of regulatory policies could both compensate for tightening the income maintenance system and contribute to reduce costs (Hvinden 2004). Moreover, as almost all women are working in the Nordic countries, there are nearly no spare labor force in this category (Hussein \& Manthorpe 2005). If recruitment from new pools of workers fail and high rates of LTSA among caring professionals prevail, Nordic countries are lacking work-family facilitating policies, which could compensate for a lack of workers. This could, in turn, coupled with declining coverage levels, endanger the high female labor market participation (Martens 2018) of which many are caring professionals.

\section{Conclusion}

The present study contributes to the literature by providing a nuanced and detailed analysis of inter-professional differences in risk of LTSA using longitudinal population data following professional careers for up to 11 years. By exploring the intersection between SEP, caring work, and gender, the study assesses the importance of sociodemographic and labor market factors and offers a reliable account of the relative prevalence of LTSA among professionals. Both low SEP and caring work were associated with a higher risk of LTSA, and especially a combination of both. While the two dimensions captured the differences in risk well, there was some overlap between professional groups. Moreover, although the association was partly explained by differences in sociodemographic and labor market characteristics, there were still substantial differences in risk of LTSA after accounting for these factors. Regarding gender, the pattern was similar for men and women with the relative risk of LTSA to some extent higher for male caring professionals. Considering the emerging shortage of care workers, the higher prevalence of LTSA among low SEP caring professionals, as found in this study, highlights the importance of investigating the determinants and consequences of absence among this group.

\section{References}

Aagestad C, Tyssen R, Johannessen HA, et al. (2014). Psychosocial and organizational risk factors for doctor-certified sick leave: a prospective study of female health and social workers in Norway, BMC Public Health 14: 1016. doi: https://doi.org/10.1186/14712458-14-1016.

Aagestad C, Johannessen HA, Tynes T, et al. (2014). Work-related psychosocial risk factors for long-term sick Leave: a prospective study of the general working population in Norway, Journal of Occupational and Environmental Medicine 56(8): 787-793. doi: https:// doi.org/10.1097/JOM.0000000000000212.

Aagestad C, Tyssen R, and Sterud T (2016). Do work-related factors contribute to differences in doctor-certified sick leave? A prospective study comparing women in health and social occupations with women in the general working population, BMC Public Health 16: 235. doi: https://doi.org/10.1186/s12889-016-2908-1.

Abbott A (1988). The System of Professions: An Essay on the Division of Expert Labor, Chicago: University of Chicago Press. 
Abbott P and Wallace C (1990). The Sociology of the Caring Professions, London: Falmer Press.

Ahola K, Kivimäki M, Honkonen T, et al. (2008). Occupational burnout and medically certified sickness absence: a population-based study of Finnish employees, Journal of Psychosomatic Research 64(2): 185-193. doi: https://doi.org/10.1016/i.jpsychores.2007.06.022.

Allebeck P and Mastekaasa A (2004) Chapter 5. Risk factors for sick leave - general studies, Scandinavian Journal of Public Health 32(63 suppl): 49-108. doi: https://doi.org/10. 1080/14034950410021853.

Allison PD (2014) Event History and Survival Analysis, Second edition, Quantitative Applications in the Social Sciences. SAGE Publications Ltd.

Andersen LL, Clausen T, Mortensen OS, et al. (2012). A prospective cohort study on musculoskeletal risk factors for long-term sickness absence among healthcare workers in eldercare, International Archives of Occupational and Environmental Health 85(6): 615-622. doi: https://doi.org/10.1007/s00420-011-0709-5.

Anttonen A and Zechner M (2011). Theorizing care and care work. In: Pfau-Effinger B and Rostgaard T (eds) Care between Work and Welfare in European Societies. Work and Welfare in Europe, Palgrav Macmillan, pp. 15-34.

Aronsson G, Gustafsson K and Dallner M (2000). Sick but yet at work. An empirical study of sickness presenteeism, Journal of Epidemiology and Community Health 54(7): 502-509. doi: https://doi.org/10.1136/jech.54.7.502.

Bambra C (2011). Health inequalities and welfare state regimes: theoretical insights on a public health 'puzzle', Journal of Epidemiology \& Community Health 65(9): 740-745. doi: https://doi.org/10.1136/jech.2011.136333.

Bambra C (2013) States of health. Welfare regimes, health, and healthcare. In: The Routledge Handbook of the Welfare State, Routledge.

Barron DN and West E (2007). The emotional costs of caring incurred by men and women in the British labour market, Social Science \& Medicine 65(10): 2160-2171. doi: https:// doi.org/10.1016/j.socscimed.2007.06.027.

Borritz M, Christensen KB, Bültmann U, et al. (2010). Impact of burnout and psychosocial work characteristics on future long-term sickness absence. Prospective results of the Danish PUMA study among human service workers, Journal of Occupational and Environmental Medicine 52(10): 964-970. doi: https://doi.org/10.1097/JOM.0b013e3181f12f95.

Box-Steffensmeier JM and Jones BS (2004). Event History Modeling. A Guide for Social Scientists. Analytical Methods for Social Research, New York: Cambridge University Press.

Box-Steffensmeier JM and Zorn C (2002) Duration models for repeated events, The Journal of Politics 64(4): 1069-1094. doi: https://doi.org/10.1111/1468-2508.00163.

Brage S (2007). Trender i de skandinaviske sykefraværsordningene [Trends in the Scandinavian sick leave schemes], Arbeid og velferd (2): 24-29.

Brante T (2013). The professional landscape: the historical development of professions in Sweden, Professions and Professionalism 3(2). doi: https://doi.org/10.7577/pp.558.

Brante T, Johnsson E, Olofsson G, et al. (2015). Professionerna I Kunskapssamhället: En Jämförande Studie Av Svenska Professioner [Professions in the Knowledge Society: A Comparative Study of Swedish Professions], Stockholm: Liber.

Bryngelson A (2009). Long-term sickness absence and social exclusion, Scandinavian Journal of Public Health 37(8): 839-845. doi: https://doi.org/10.1177/1403494809346871.

Bryngelson A, Hertzman JB and Fritzell J (2011). The relationship between gender segregation in the workplace and long-term sickness absence in Sweden, Scandinavian Journal of Public Health: 1403494811414242. doi: https://doi.org/10.1177/1403494811414242.

Christensen KB, Andersen PK, Smith-Hansen L, et al. (2007). Analyzing sickness absence with statistical models for survival data, Scandinavian Journal of Work, Environment $\&$ Health 33(3): 233-239. DOI: https://doi.org/10.5271/sjweh.1132. 
Christensen KB, Labriola M, Lund T, et al. (2008). Explaining the social gradient in longterm sickness absence: a prospective study of Danish employees, Journal of Epidemiology and Community Health 62(2): 181-183. doi: https://doi.org/10.1136/jech.2006.056135.

Dahl S-Å, Hansen H-T and Olsen KM (2010) Sickness absence among immigrants in Norway, 1992-2003, Acta Sociologica 53(1): 35-52. doi: https://doi.org/10.1177/ 0001699309357841.

Dahl S-Å, Hansen H-T and Vignes B (2015). His, her, or their divorce? Marital dissolution and sickness absence in Norway, Journal of Marriage and Family 77(2): 461-479. doi: https://doi.org/10.1111/jomf.12166.

Dale-Olsen H and Markussen S (2010). Økende sykefravær over tid? Sykefravær, arbeid og trygd 1972-2008. [Increasing sickness absence over time? Sickness absence, work and social insurance], Søkelys på arbeidslivet 27(01-02): 105-121.

Dill J, Erickson RJ and Diefendorff JM (2016). Motivation in caring labor: implications for the well-being and employment outcomes of nurses, Social Science \& Medicine 167: 99-106. doi: https://doi.org/10.1016/j.socscimed.2016.07.028.

England P, Budig M and Folbre N (2002). Wages of virtue: the relative pay of care work, Social Problems 49(4): 455-473. doi: https://doi.org/10.1525/sp.2002.49.4.455.

Esping-Andersen G (1999). Social Foundations of Postindustrial Economies, Oxford: Oxford University Press.

Etzioni A (1969). The Semi-Professions and Their Organization: Teachers, Nurses, Social Workers, Free Press.

European Commission (2014). Mapping and Analyzing Bottleneck Vacancies in EU Labour Markets - Overview Report, Luxembourg: Publications Office of the European Union.

Evans O and Steptoe A (2002). The contribution of gender-role orientation, work factors and home stressors to psychological well-being and sickness absence in male- and female-dominated occupational groups, Social Science \& Medicine 54(4): 481-492. doi: https://doi.org/10.1016/S0277-9536(01)00044-2.

Foverskov E and Holm A (2015) Socioeconomic inequality in health in the British household panel: Tests of the social causation, health selection and the indirect selection hypothesis using dynamic fixed effects panel models, Social Science \& Medicine 150: 172-183. doi: https://doi.org/10.1016/j.socscimed.2015.12.021.

Freidson E (2001). Professionalism: The Third Logic, John Wiley \& Sons.

Galobardes B, Shaw M, Lawlor DA, et al. (2006a). Indicators of socioeconomic position (part 1), Journal of Epidemiology \& Community Health 60(1): 7-12. doi: https://doi. org/10.1136/jech.2004.023531.

Galobardes B, Shaw M, Lawlor DA, et al. (2006b). Indicators of socioeconomic position (part 2), Journal of Epidemiology \& Community Health 60(2): 95-101. doi: https://doi. org/10.1136/jech.2004.028092.

Ganzeboom HBG and Treiman DJ (1996). Internationally comparable measures of occupational status for the 1988. International Standard Classification of Occupations, Social Science Research 25(3): 201-239. doi: https://doi.org/10.1006/ssre.1996.0010.

Grusky DB (2005). Foundations of a neo-Durkheimian class analysis. In: Wright EO (ed.) Approaches to Class Analysis, Cambridge University Press, pp. 51-81.

Gunnes T and Knudsen P (2015). Tilbud og etterspørsel for ulike typer lærere mot 2040: Framskrivinger basert på LÆRERMOD [Supply and demand for different kinds of teachers towards 2040: Projections based on LÆRERMOD]. 41, Oslo-Kongsvinger: Statistisk sentralbyrå.

Gustafsson K and Marklund S (2011). Consequences of sickness presence and sickness absence on health and work ability: a Swedish prospective cohort study, International Journal of Occupational Medicine and Environmental Health 24(2): 153-165. doi: https:// doi.org/10.2478/s13382-011-0013-3. 
Hagelund A and Bryngelson A (2014) Change and resilience in welfare state policy. The politics of sickness insurance in Norway and Sweden, Social Policy \& Administration 48(3): 300-318. doi: https://doi.org/10.1111/spol.12009.

Halbesleben JRB, Wakefield BJ, Wakefield DS, et al. (2008). Nurse burnout and patient safety outcomes: nurse safety perception versus reporting behavior, Western Journal of Nursing Research 30(5): 560-577. doi: https://doi.org/10.1177/0193945907311322.

Halmos P (1967). The personal service society, The British Journal of Sociology 18: 13-28. doi: https://doi.org/10.2307/588586.

Hochschild AR (2003). The Managed Heart: Commercialization of Human Feeling, Twentieth Anniversary Edition, With a New Afterword, University of California Press.

Hussein S and Manthorpe J (2005) An international review of the long-term care workforce, Journal of Aging \& Social Policy 17(4): 75-94. doi: https://doi.org/10.1300/ J031v17n04 05.

Hvinden B (2004). Nordic disability policies in a changing Europe: is there still a distinct Nordic model? Social Policy \& Administration 38(2): 170-189. doi: https://doi.org/10.1111/ j.1467-9515.2004.00384.x.

Indregard A-MR, Knardahl S and Nielsen MB (2017). Emotional dissonance and sickness absence: A prospective study of employees working with clients, International Archives of Occupational and Environmental Health 90(1): 83-92. doi: https://doi.org/10.1007/ s00420-016-1176-9.

Ingstad K and Kvande E (2011). Arbeid i sykehjem - for belastende for heltid? [Work in elder care - to demanding for full-time work?], Søkelys på arbeidslivet 28(01-02): 42-55.

Kamp A and Dybbroe B (2016). Struggles of professionalism and emotional labour in standardized mental health care, Nordic Journal of Working Life Studies 6(S1): 67-86. doi: https://doi.org/10.19154/njwls.v6i1.4886.

Kangas O and Kvist J (2013). Nordic welfare states. In: The Routledge Handbook of the Welfare State, Routledge.

Karasek RA Jr (1979). Job demands, job decision latitude, and mental strain: implications for job redesign, Administrative Science Quarterly 24(2): 285-308. doi: https://doi.org/10. $2307 / 2392498$.

Kivimäki M, Forma P, Wikström J, et al. (2004). Sickness absence as a risk marker of future disability pension: The 10-town study. Journal of Epidemiology and Community Health 58(8): 710-711. DOI: https://doi.org/10.1136/jech.2003.015842.

Larson MS (1977). The Rise of Professionalism. A Sociological Analysis, Berkeley: University of California Press.

Löve J, Hensing G, Holmgren K, et al. (2013) Explaining the social gradient in sickness absence: a study of a general working population in Sweden, BMC Public Health 13: 545. doi: https://doi.org/10.1186/1471-2458-13-545.

Lund T, Labriola M, Christensen KB, et al. (2005). Psychosocial work environment exposures as risk factors for long-term sickness absence among Danish employees: results from DWECS/DREAM, Journal of Occupational and Environmental Medicine 47(11): 1141-1147. doi: https://doi.org/10.1097/01.jom.0000174301.80318.f2.

Lund T, Labriola M, Christensen KB, et al. (2006). Physical work environment risk factors for long term sickness absence: prospective findings among a cohort of 5357 employees in Denmark, British Medical Journal 332(7539): 449-452. doi: https://doi.org/10.1136/ bmj.38731.622975.3A.

Lund T, Labriola M and Villadsen E (2007). Who is at risk for long-term sickness absence? A prospective cohort study of Danish employees, Work: A Journal of Prevention, Assessment and Rehabilitation 28(3): 225-230.

Martens CT (2018). Eldercare policies in Scandinavia between 1993 and 2014: increased facilitation of family caregiving? Nordic Journal of Social Research 9: 48-67. doi: https:// doi.org/10.7577/njsr.2145. 
Maslach C (2003). Burnout: The Cost of Caring, ISHK.

Mastekaasa A (2008). Profesjon og arbeidsmarked [Profession and labor market]. In: Molander A and Terum LI (eds) Profesjonsstudier, Oslo: Universitetsforlaget.

Mastekaasa A (2012) Dependent children and women's sickness absence in the EU countries and Norway, European Societies 15(5): 686-706. Doi: https://doi.org/10.1080/1461669 6.2012.721892.

Mastekaasa A (2016). Sykefravær i offentlig og privat sektor [Sickness absence in the public and private sector], Søkelys på arbeidslivet 32(04): 311-326.

Melchior M, Krieger N, Kawachi I, et al. (2005). Work factors and occupational class disparities in sickness absence: findings from the GAZEL cohort study, American Journal of Public Health 95(7): 1206-1212. doi: https://doi.org/10.2105/AJPH.2004.048835.

Melsom AM and Mastekaasa A (2017). Gender, occupational gender segregation and sickness absence: longitudinal evidence, Acta Sociologica: 0001699317691583. doi: https:// doi.org/10.1177/0001699317691583.

Merkus SL, Drongelen A van, Holte KA, et al. (2012). The association between shift work and sick leave: a systematic review, Occup Environ Med 69(10): 701-712. doi: https:// doi.org/10.1136/oemed-2011-100488.

Messing K, Punnett L, Bond M, et al. (2003). Be the fairest of them all: challenges and recommendations for the treatment of gender in occupational health research, American Journal of Industrial Medicine 43(6): 618-629. doi: https://doi.org/10.1002/ajim.10225.

Michélsen H, Sebrant U and Schulman A (2014). Intervention to prevent mental ill-health among health care workers, Nordic Journal of Working Life Studies 4(2): 117-138. doi: https://doi.org/10.19154/njwls.v4i2.3867.

Michie S and Williams S (2003). Reducing work related psychological ill health and sickness absence: a systematic literature review, Occupational and Environmental Medicine 60(1): 3-9. doi: https://doi.org/10.1136/oem.60.1.3.

Moos L (2004). Relationsprofessioner - hvem er de? [Relational Professionals - Who Are They?]. In: Moos L, Krejsler J, and Laursen PF (eds) Relationsprofessioner: Lærere, Pædagoger, Sygeplejersker, Sundhedsplejersker, Socialrådgivere Og Mellemledere, København: Danmarks Pædagogiske Universitets Forlag, pp. 7-16.

Murphy R (1988) Social Closure: The Theory of Monopolization and Exclusion, Clarendon Press.

Niedhammer I, Chastang J-F, David S, et al. (2008). The contribution of occupational factors to social inequalities in health: findings from the national French SUMER survey, Social Science \& Medicine 67(11): 1870-1881. doi: https://doi.org/10.1016/j.socscimed. 2008.09.007.

OECD (2013). Mental Health and Work: Norway, OECD Publishing.

Oesch D (2006). Coming to grips with a changing class structure an analysis of employment stratification in Britain, Germany, Sweden and Switzerland, International Sociology 21(2): 263-288. doi: https://doi.org/10.1177/0268580906061379.

Oulton JA (2006). The global nursing shortage: an overview of issues and actions, Policy, Politics, \& Nursing Practice 7(3_suppl): 34S-39S. doi: https://doi.org/10.1177/ 1527154406293968.

Piha K, Laaksonen M, Martikainen P, et al. (2010). Interrelationships between education, occupational class, income and sickness absence, European Journal of Public Health 20(3): 276-280. doi: https://doi.org/10.1093/eurpub/ckp162.

Rieck KME and Telle K (2013). Sick leave before, during and after pregnancy, Acta Sociologica 56(2): 117-137. doi: https://doi.org/10.1177/0001699312468805.

Roksvaag K and Texmon I (2012). Arbeidsmarkedet for helse- og sosialpersonell fram mot år 2035 - Dokumentasjon av beregninger med HELSEMOD 2012 [The labor market for health and social services towards year 2035 - Documentation of estimations by HELSEMOD 2012]. 14, Oslo-Kongsvinger: Statistisk sentralbyrå. 
Rugulies R, Christensen KB, Borritz M, et al. (2007). The contribution of the psychosocial work environment to sickness absence in human service workers: results of a 3-year follow-up study, Work \& Stress 21(4): 293-311. doi: https://doi.org/10.1080/02678370701747549.

Spector PE, Zhou ZE and Che XX (2014). Nurse exposure to physical and nonphysical violence, bullying, and sexual harassment: a quantitative review, International Journal of Nursing Studies 51(1): 72-84. doi: https://doi.org/10.1016/j.ijnurstu.2013.01.010.

Trydegård G-B (2012). Care work in changing welfare states: Nordic care workers' experiences, European Journal of Ageing 9(2): 119-129. doi: https://doi.org/10.1007/s10433012-0219-7.

Tufte PA (2013). Risky professions? Risk of disability in professions in Norway, Professions and Professionalism 3(1). doi: https://doi.org/10.7577/pp.468.

Vahtera J, Pentti J and Kivimäki M (2004). Sickness absence as a predictor of mortality among male and female employees, Journal of Epidemiology and Community Health 58(4): 321-326. DOI: https://doi.org/10.1136/jech.2003.011817.

Warming K (2013). Men who stop caring: the exit of men from caring occupations, Nordic Journal of Working Life Studies 3(4): 4-19. doi: https://doi.org/10.19154/njwls.v3i4. $\underline{3070 .}$.

Wharton AS (1993). The affective consequences of service work: managing emotions on the job, Work and Occupations 20(2): 205-232. doi: https://doi.org/10.1177/07308884930 20002004 .

Wieclaw J, Agerbo E, Mortensen PB, et al. (2006). Risk of affective and stress related disorders among employees in human service professions, Occupational and Environmental Medicine 63(5): 314-319. doi: https://doi.org/10.1136/oem.2004.019398. 


\section{Appendix}

Figure A I. Relative risk (hazard ratio) of long-term sickness absence for men according to type of professional. Robustness check of impact of omitted professionals on estimate for type of profession.

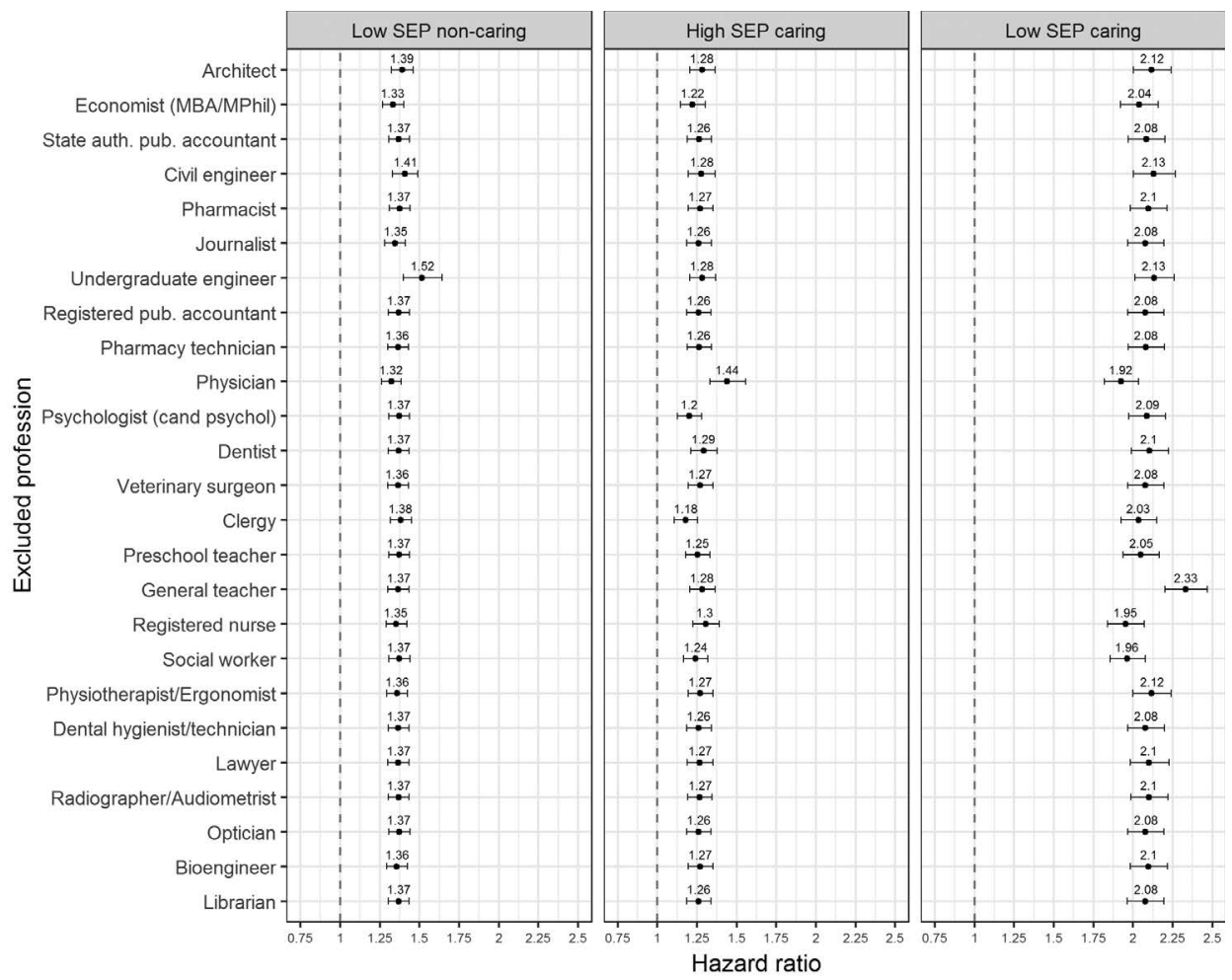

Note: Reference category = High SEP non-caring professionals; adjusted for marital status, pregnancy, number of children under 18, immigration status, part-time work, income, sector, percent of women at workplace, centrality of workplace, prior sickness absence; year of birth fixed effects; stratified by order of events; Cox proportional regression model: Norway 2003-2013. 
Figure A2. Relative risk (hazard ratio) of long-term sickness absence for women according to type of professional. Robustness check of impact of omitted professionals on estimate for type of profession.

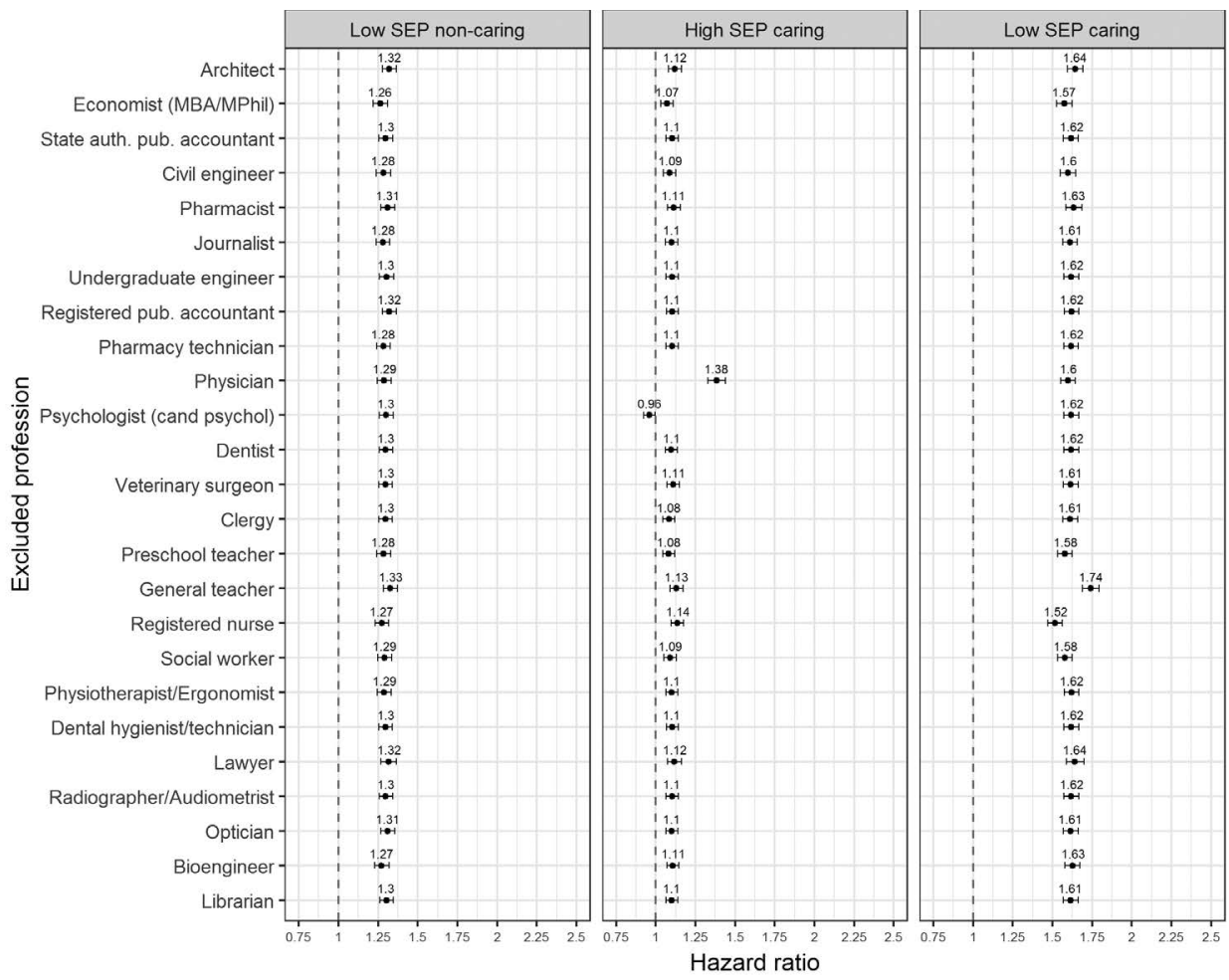

Note: Reference category = High SEP non-caring professionals; adjusted for marital status, pregnancy, number of children under 18, immigration status, part-time work, income, sector, percent of women at workplace, centrality of workplace, prior sickness absence; year of birth fixed effects; stratified by order of events; Cox proportional regression model: Norway 2003-20I3. 


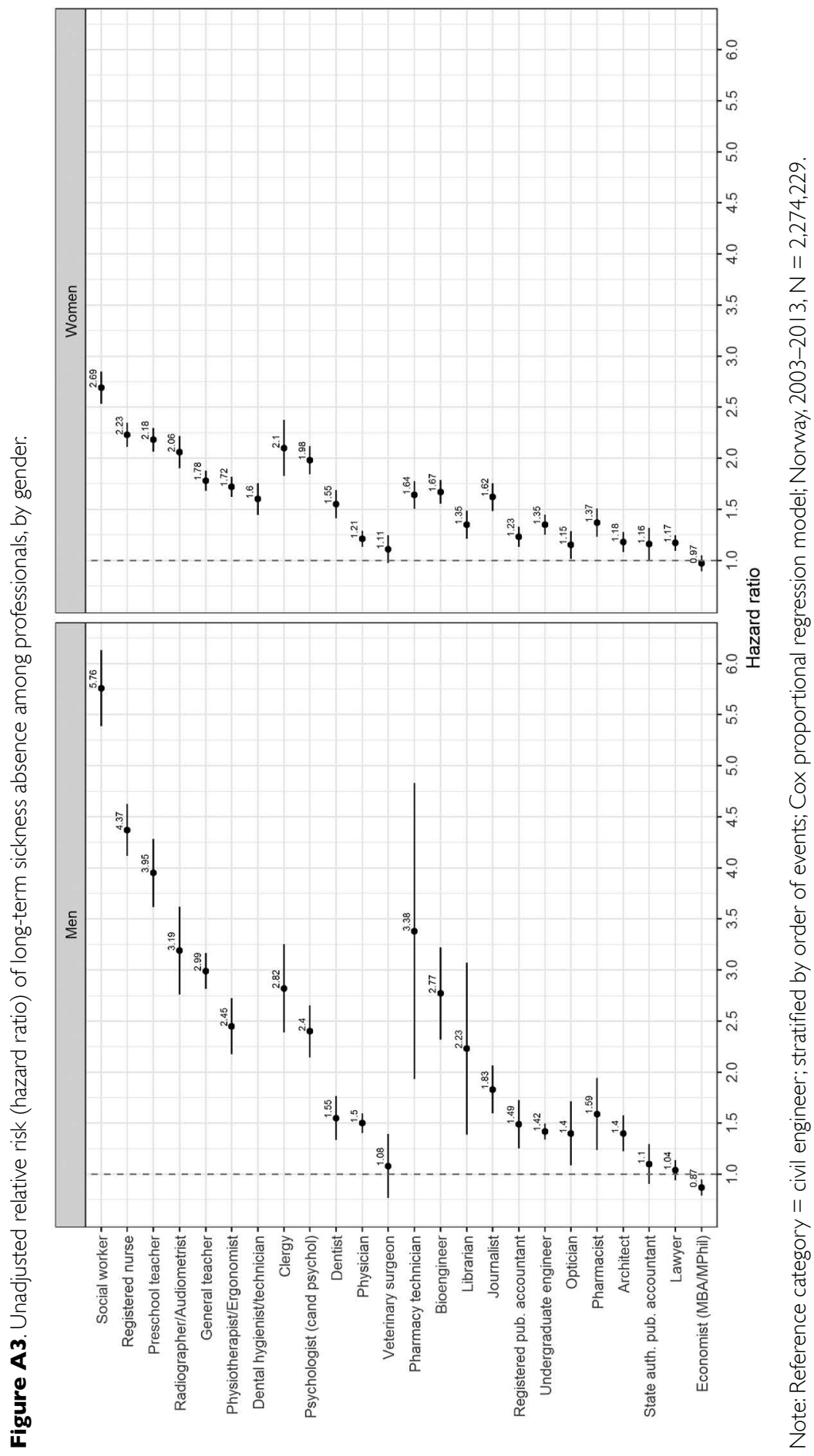

